\title{
Spatial and temporal patterns of coral black band disease in relation to a major sewage outfall
}

\author{
Ross Jones $^{1, *}{ }^{,}$Rodney Johnson ${ }^{2}$, Tim Noyes ${ }^{2}$, Rachel Parsons ${ }^{2}$ \\ ${ }^{1}$ Australian Institute of Marine Science, The UWA Oceans Institute (M096), 35 Stirling Highway, Crawley, \\ Western Australia 6009, Australia \\ ${ }^{2}$ Bermuda Institute of Ocean Sciences (BIOS), 17 Biological Lane, St Georges, Bermuda GE01
}

\begin{abstract}
Spatial and temporal patterns of coral black band disease (BBD) prevalence were examined during the summers of 2004 to 2008 at 10 reef sites located along a sewage gradient on either side of a major marine outfall on Bermuda's south shore. The gradient was identified by current meter and drogue deployments and confirmed by a water quality monitoring using fecal indicator bacteria (gastrointestinal enterococci) as a sewage marker. BBD prevalence was also examined at 22 locations across the Bermuda platform in different physiographic reef zones, identified by reef survey techniques and analysis of community composition. BBD prevalence was generally low and was recorded in Diploria strigosa $>$ Montastraea franksi $>$ M. cavernosa = D. labyrinthiformis $>$ Porites astreoides and the hydrocoral Millepora alcicornis. Most occurrences were in D. strigosa, and BBD prevalence was highest on the outer rim reef (range: 0.3 to $1.9 \%$ ), followed by the outer lagoonal patch reefs (range: 0.05 to $0.8 \%$ ) and the deeper terrace reefs (range: 0.1 to $0.2 \%$ ). BBD prevalence levels decreased over the study period, and BBD was only rarely observed in $D$. labyrinthiformis, which appears to be immune to infection in Bermuda. The BBD prevalence in $D$. strigosa was lower on reefs regularly exposed to sewage than on the near pristine outer rim reef sites, which experience the exceptional water quality characteristics of the oligotrophic North Atlantic gyre.
\end{abstract}

KEY WORDS: Coral $\cdot$ Black band disease $\cdot$ Sewage $\cdot$ Bermuda Resale or republication not permitted without written consent of the publisher

\section{INTRODUCTION}

Disease is an important factor affecting the composition, structure and dynamics of coral communities (Edmunds 1991, Hughes 1994, Hayes \& Goreau 1998, Goreau et al. 1998, Aronson \& Precht 2001, Weil et al. 2002). Nevertheless, the pathology, etiology and epizootiology of most coral diseases remain poorly understood (Richardson 1998, Weil et al. 2002). In particular, the link between disease prevalence and anthropogenic pollution is one of the least understood areas (Richardson 1998, Kuta \& Richardson 2002). However, it has been suggested that for coral black band disease (BBD), there is an obvious spatial and temporal relationship with pollution, that it is common in polluted shallow water, that the largest impacts are in areas near sewage outfalls and that it has spread in time and space as human developments spread along coastlines (Goreau et al. 1998).

It was on Bermuda's reefs that BBD was first described by Garrett \& Ducklow (1975). This was the first coral disease published in the scientific literature (preceding Antonius 1976, which is always incorrectly cited as having been published in 1973). BBD is a highly conspicuous disease, characterized by a dark, cyanobacterial-dominated, sulfide-rich band that migrates over the surface of corals at rates of several $\mathrm{mm} \mathrm{d}^{-1}$, lysing the coral tissue (Rützler \& Santavy 1983). The disease is thought to be caused by a consortium of microorganisms and may not have a primary pathogen (Richardson 1998, 2004, FriasLopez et al. 2004). BBD is recognized as one of the 
most widespread diseases in the Caribbean and adjacent waters (Antonius 1981, Weil 2004), primarily infecting massive frameworkbuilding scleractinian corals, including Diploria spp., Montastraea spp., Colpophyllia natans and Siderastrea siderea (Antonius 1981, Edmunds 1991, Sutherland et al. 2004). The disease is now recognized as having a global distribution (Sutherland et al. 2004).

A number of field studies have suggested a link between sewage pollution and BBD outbreaks. Taylor (1983) reported an association between BBD prevalence and sewage pollution or poor water quality, but the study does not show any data, and reference is made to other still unpublished work by the same author suggesting the association. Antonius (1985) purports to show a link between disease frequency and sewage pollution, but again, the evidence is based upon a perceptible increase in BBD frequency near a sewage outfall; no data are shown. Kaczmarsky et al. (2005) recorded a significantly higher prevalence of BBD and White Plague type II in corals at a single location compared to a single control site $2.5 \mathrm{~km}$ away. The site where the disease prevalence was higher was occasionally exposed to un-treated sewage (during emergency sewage bypass events). Kuta \& Richardson (2002) found a positive relationship between elevated nitrite and BBD prevalence in Florida but did not find an overall positive correlation with the more readily assimilable nutrient species. Overall, the results are difficult to interpret, and any relationship between poor water quality and BBD remains obscure (Richardson 2004).

Located in the mid-Atlantic $\sim 1500 \mathrm{~km}$ north of the Caribbean and $1000 \mathrm{~km}$ east-southeast of the US, Bermuda is made up of a crescent-shaped chain of $\sim 150$ islands (land area of $53 \mathrm{~km}^{2}$ ) restricted to the SE corner of an atoll-like elliptical reef tract (Morris et al. 1977). Bermuda is highly geographically isolated and generally recognized as containing the most northerly reefs of the Atlantic (Spalding et al. 2001). With just over 30 hard coral species, the reefs are depauperate compared to the $>65$ species (from $>20$ genera) reported in the Caribbean (Stehli \& Wells 1971, Wells 1973, Sterrer 1986, Logan 1988).

Bermuda is densely populated, and surveys of chemical contamination of sediments have identified a number of pollution 'hotspots' (Jones 2011), including a reef beside a marine landfill (seafill), which was proposed as the most contaminated reef in the world (Jones 2010). Recent surveys of sewage pollution have also shown a number of areas with high fecal indicator bacteria (gastrointestinal enterococci) in seawater and areas where sediments contain the human specific bacterial biomarker Bacteroides and elevated concentrations of the fecal biomarker coprostanol (5 $\beta$-cholestan-3- $\beta$-ol; Jones et al. 2011).

The sewage (and chemical) pollution 'hotspots' are invariably located inshore, in enclosed bays, harbors, marinas and where there are houses or light industry located close to the shoreline (Jones 2011, Jones et al. 2011). The patch reefs of the Bermuda lagoon and offshore, outer reef systems are relatively contaminant-free (Jones 2011), probably due to the absence of any river systems that can transport anthropogenic material offshore. There is, however, a large sewage outfall on Bermuda's south shore which continuously discharges $\sim 2.5 \times 10^{6}$ to $5 \times 10^{6} \mathrm{l} \mathrm{d}^{-1}$ of virtually untreated sewage. The outfall (Seabright Point) was established in 1992 and serves the capital city of Hamilton and surrounding areas, a local hospital and cruise ships docked at Hamilton during the summer months. Prior to discharge, the sewage is only subject to preliminary treatment, which involves maceration (i.e. grinding up of soft solids), screening (i.e. straining for solid trash) and removal of sand and larger inorganic particles (see Tchobanoglous \& Kreith 2002). The sewage is released over a $\sim 100 \mathrm{~m}$ long area through a series of ten $1.5 \mathrm{~m}$ high riser jets (which discharge alternately in opposite directions) and through a terminal (end) diffuser, which is mounted $\sim 1 \mathrm{~m}$ above the seabed. The end diffuser is $\sim 630 \mathrm{~m}$ from the shore and close to the deeper (15 to $18 \mathrm{~m}$ ) main terrace reef system (see Logan 1988 for terminologies). Sewage disposal options and practices in Bermuda are discussed further by Jones et al. (2011).

Bermuda's reefs are considered to be under significant environmental pressure (see Burke \& Maidens 2004), because of the high population density and because reefs with low species diversity have a low capacity to absorb a disturbance due to low functional redundancy, i.e. they have a low resilience (Folke et al. 2004). Coral growth is also limited in high-latitude reefs by lower water temperatures and aragonite saturation state (Kleypas et al. 2001), and highly isolated reefs are also likely to recover more slowly from disturbances than central, more interconnected populations (Hughes et al. 2003). In vulnerable reef systems, the effect of anthropogenic agents (such as sewage pollution) on disturbance agents like BBD is of particular interest, since pollution can be theoretically prevented, unlike the disturbances related to climate change.

We conducted hydrological studies around the sewage outfall on Bermuda's south shore to guide selection of survey sites along a putative sewage con- 
tamination gradient. We confirmed the gradient by testing for fecal indicator bacteria (enterococci) and then, in annual surveys conducted over a $5 \mathrm{yr}$ period, examined BBD prevalence on reefs along the gradient. To provide a wider context for these studies and to examine the significance of BBD as a factor structuring the reef communities of Bermuda, we also examined the composition, coral distribution patterns and BBD prevalence in different physiographic reef zones across the Bermuda platform. The results are discussed in terms of the links between BBD and sewage pollution but also in terms of the overall risk posed by BBD to these highly isolated, high latitude reefs of Bermuda.

\section{MATERIALS AND METHODS}

\section{Spatial patterns of coral cover and disease prevalence}

Videographic surveys of the coverage of major benthic groups were conducted at multiple locations across the Bermuda platform encompassing different physiographic reef zones (using the terminology of Logan 1988), including the platform margin reefs (i.e. rim reefs, 8 to $10 \mathrm{~m}$ depth; A, A2, B and B2 in Fig. 1A), offshore lagoonal patch reefs (3 to $5 \mathrm{~m}$ depth; $\mathrm{C}, \mathrm{C} 2$, $\mathrm{D}$ and D2 in Fig. 1A,B), nearshore patch reefs (3 to $5 \mathrm{~m}$ depth; E, E2, F and F2 in Fig. 1A,B), inshore patch reefs ( 3 to $5 \mathrm{~m}$ depth; $\mathrm{G}$ and $\mathrm{G} 2$ in Fig. $1 \mathrm{~A}, \mathrm{~B}$ ), inshore fringing reefs ( 3 to $5 \mathrm{~m}$ depth; $\mathrm{H}$ and $\mathrm{H} 2$ in Fig. $1 \mathrm{~A}, \mathrm{~B}$ ) and main terrace reefs (15 to $18 \mathrm{~m}$ depth; $\mathrm{I}_{\text {, }}$ $\mathrm{I} 2, \mathrm{~J}, \mathrm{~J} 2, \mathrm{~K}$ and $\mathrm{K} 2$ in Fig. $1 \mathrm{~A}, \mathrm{~B})$. All of the monitoring sites were established in 2004, except sites $\mathrm{H}$ and H2, which were established in 2005. Video surveys were conducted from mid-July to mid-September each year.

At each 'location' within a physiographic reef zone, 2 study sites were chosen (i.e. A, A2 or B, B2, etc.) separated by a distance of at least $300 \mathrm{~m}$. At each 'site', generally an individual reef, five $30 \mathrm{~m}$ parallel permanent transects were established, separated from each other by a distance of at least 3 to $5 \mathrm{~m}$. The start, middle and end of the transect lines were marked with a 30 to $40 \mathrm{~cm}$ section of $15 \mathrm{~mm}$ galvanized reinforcing rod hammered into the reef.

During surveys, the reef was recorded using a digital video recorder mounted in an underwater video housing. Filming followed the contours of the reef, perpendicular to and $0.5 \mathrm{~m}$ from the reef, and was conducted between 09:00 and 15:30 h for optimum lighting conditions. In the laboratory, 50 nonoverlapping still images were captured from each transect line video using video editing software. The software program CPCe (Coral Point Count, NCRI) was used for image processing (Kohler \& Gill 2006) using 10 points randomly distributed across each of
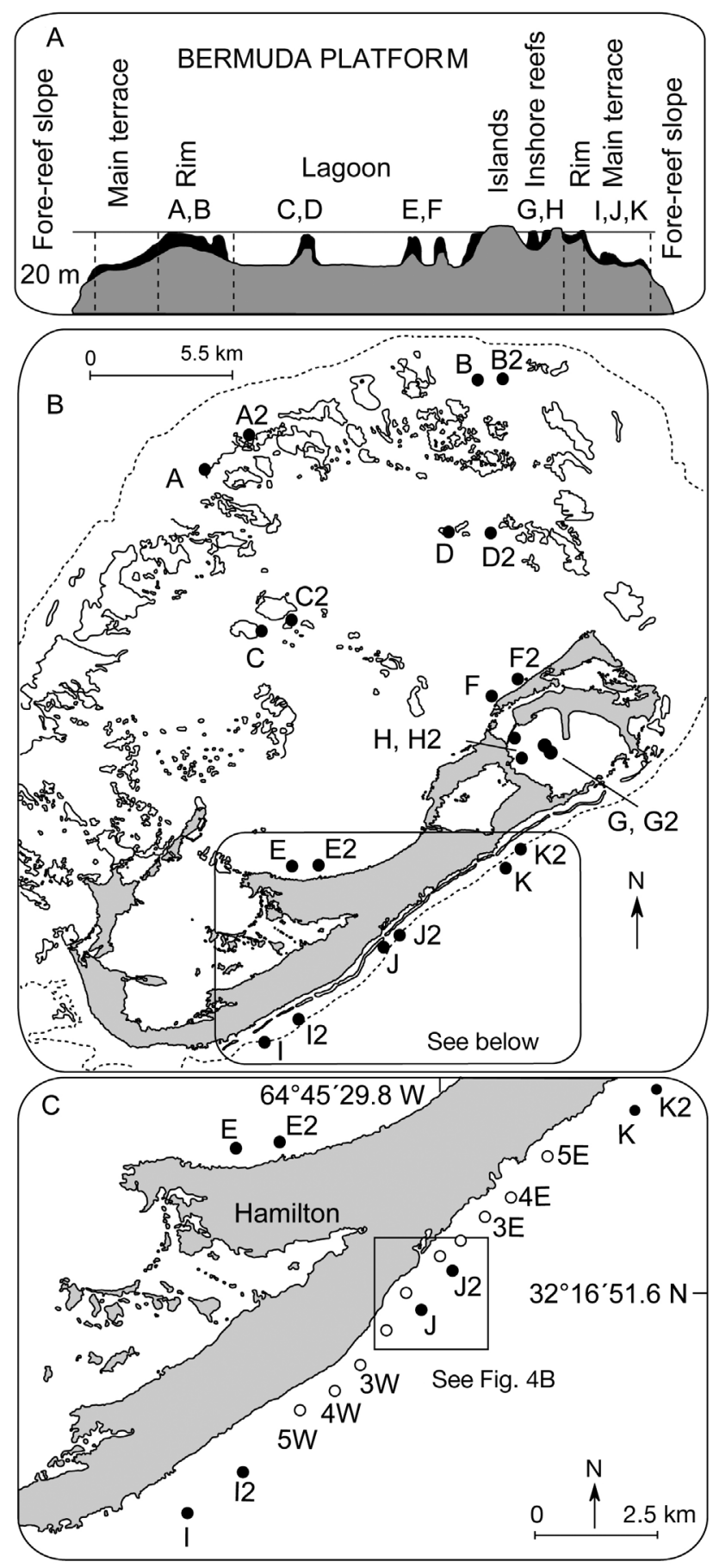

Fig. 1. $(\mathrm{A}, \mathrm{B})$ Long-term video monitoring sites and disease monitoring locations (,$A$ to $\mathrm{K}$ ). (C) 10 coral disease survey sites along the south shore of Bermuda (O,W \& E), centered around the Seabright Point sewage outfall 
the 50 images from a given transect, and the coral species or substrate lying under these points was identified. For CPCe analysis, 12 categories specific to Bermuda were used including 9 'living' categories (i.e. 'hard corals', 'gorgonians', etc.) and 3 'non-living' categories (sand, rock or rubble, etc.). Organisms were identified to the highest level of taxonomic certainty.

\section{Hydrological studies}

The flow characteristics around the Seabright Point sewage outfall were investigated to understand the dispersion of the sewage plume and guide placement of the ecological survey and water quality survey sites along a sewage gradient. Current speed and direction was measured with an Aanderaa, RCM 9 MkII acoustic doppler current meter (Aanderaa Nesttunbrekken 97, 5221 Nesttun) deployed 30 m SE of the outfall at mid-water (i.e. $\sim 10 \mathrm{~m}$ depth, to avoid noise from wave pumping) using a mooring weight and subsurface buoy. The current meter was set to record at 10 min intervals the speed and direction, which were calculated as vector averages for the sampling period, and the pressure and temperature readings were taken every $10 \mathrm{~min}$. Wind speed and direction data for these deployments were provided by the Bermuda Weather Service as recorded at the Bermuda International Airport.

Currents in the vicinity of the outfall have been examined by drogue studies in 1973 by the Bermuda Government, then the Ministry of Works and Agriculture, as part of an investigation of potential offshore outfall sites. In the absence of any major modification to the shoreline in the interim period that may affect flow regimes, the results of the drogue studies are considered still applicable, and the results of the study have been included to supplement the eulerian studies described above. In the study, drogues were deployed at 1, 3 and $9 \mathrm{~m}$ deep and allowed to drift, and their positions were fixed after $1 \mathrm{~h}$ and $2 \mathrm{~h}$. Studies were conducted over $9 \mathrm{~d}$ under different combinations of tide and wind direction.

To examine water quality associated with the sewage outfall, seawater samples were collected along the putative sewage gradient (Sites K2, 5E, 1E, J2, J, 1W, 5W and I2 in Fig. 1B). Water samples were collected in June 2010 (on a flooding tide) and stored chilled until analysis at the Bermuda Government Department of Health within $6 \mathrm{~h}$ of collection. All of the samples were analyzed for fecal indicator bacteria (enterococci) using culture-dependent membrane filtration techniques (EPA 2000, WHO 2003), and the data were expressed as the number of colony forming units (CFUs) per $100 \mathrm{ml}$.

\section{BBD disease surveys}

During the video surveys, assessments were made of the prevalence of BBD in hard coral species and the hydrocoral Millepora alcicornis. All assessments were made along a $1 \mathrm{~m}$ band on either side of the transect tapes used in the video monitoring. To examine the relationship between BBD prevalence and proximity to the Seabright Point sewage outfall, assessments were also made on five $30 \mathrm{~m}$ parallel transects at 5 nearshore reefs (8 to $10 \mathrm{~m}$ depth) located between 0.5 and $3.3 \mathrm{~km}$ east and west of the sewage outfall, along the primary axis of sewage flow identified by hydrological studies (Sites E1 to E5 and W1 to W5 in Fig. 1B,C). Disease surveys were conducted at these sites from mid-July to midSeptember each year.

\section{Statistical analyses}

Multivariate analysis techniques were used to examine the community structure of the reefs and spatial distributions of the study species. Because 2005 was the first year in which all permanent monitoring sites were established, data from 2005 were used for the analysis. From the abundance data, hierarchical clustering analysis was used to produce dendrograms (tree diagrams) in which a series of nested groupings of sites were constructed, with biologically similar samples clustering close together and dissimilar samples spaced farther apart. Multidimensional scaling (MDS) analysis (Shepard 1962), based on Bray-Curtis similarities from square root transformed data, was then used to produce a map of the study sites that reflects their biological similarity (in terms of species, benthic class or species group) rather than cluster location.

To test for the relationship between BBD prevalence and the sewage outfall, the prevalence data were analyzed by fitting a generalized linear model (GLM) using a Poisson distribution with a log link. The model was fitted with direction, distance and their interaction, using an offset of the total number of colonies. The Poisson distribution was used because this is the most appropriate for data with small counts, and the offset takes into account the proportion of diseased coral, not just the actual count. The 
prevalence of disease was very small ( 0 to 6 cases or 0 to $5 \%$ ) in each transect line, and the transect lines were grouped together at each site to give a total number of cases for each location. Each year of measure was treated as a replicate, and the distance from the outfall was fitted as a factor.

\section{RESULTS}

\section{Spatial patterns of coral cover}

In total, 15 hard coral species were recorded during the video-monitoring program surveys of 2005. Coral cover was higher on the main terrace reefs (mean $\sim 60 \%$ hard coral cover) than the rim reef sites (mean $\sim 25 \%$ ) and lagoonal patch reefs (mean 17\%; Table 1). The inshore fringing and patch reefs (Locations $\mathrm{G}$ and $\mathrm{H}$ ) had $~ 5 \%$ hard coral cover (Table 1).

The multivariate analysis of the video-survey data shows 3 primary clusters based on $60 \%$ similarity patterns (Clusters 1 to 3 in Fig. 2A) and 2 secondary clusters (i.e. Sub-clusters 2A and 2B in Fig. 2A) based on $65 \%$ similarity patterns. The stress value associ- ated with the plot was 0.14 , indicating a good representation of between-site differences in the 2-dimensional picture. Both sites at each 'location' were always found within the same primary cluster; for example, all outer rim reef sites (i.e. Locations A and B) were located within Cluster 1, and all offshore lagoonal patch reef sites were located in Cluster 2. Similarly, the inshore fringing and patch reefs ( $G$ and $\mathrm{H}$ ) were located in Cluster 2B. The nearshore lagoonal coral-algal patch reefs of Site E formed a separate cluster (Cluster 3 in Fig. 2A).

The Diploria-Montastraea-Porites species assemblage constitutes $\sim 97 \%$ of the hard coral cover in Cluster 1 (which includes the rim reef and main terrace reef), nearly $90 \%$ of Cluster $2 \mathrm{~A}$ (lagoonal patch reefs) and nearly $70 \%$ of Cluster $2 \mathrm{~B}$ (the inshore patch and fringing reefs) but only $\sim 16 \%$ of Cluster 3 (see pie-charts in Fig. 2A, Table 1). Cluster 3 represents turbid near shore patch reefs, which, although they have an average hard coral cover of $22 \%$, are dominated by branching species, such Madracis mirabilis, M. decactis and the hydrocoral Millepora alcicornis (see pie-charts in Fig. 2A, Table 1). In Cluster 1 (which constitutes the bulk of Bermuda's reefs),

Table 1. Cover (mean percentage total cover \pm SD) of hard corals (including the hydrocoral Millepora alcicornis) and major benthic groups at the 10 video monitoring locations (see Fig. 1A), with each location comprising 2 sites. D-M-P: Diploria-

Montastraea-Porites

\begin{tabular}{|c|c|c|c|c|c|c|c|}
\hline $\begin{array}{l}\text { MDS cluster: } \\
\text { Location: }\end{array}$ & $\begin{array}{l}\text { Cluster } 1 \\
\text { A, B }\end{array}$ & $\begin{array}{l}\text { Cluster } 1 \\
\text { I, J, K }\end{array}$ & $\begin{array}{c}\text { Cluster } 1 \\
\text { A, B, I, J, K }\end{array}$ & $\begin{array}{l}\text { Cluster 2A } \\
\text { C, D, F }\end{array}$ & $\begin{array}{l}\text { Cluster 2B } \\
\text { G, H }\end{array}$ & $\begin{array}{c}\text { Cluster } 3 \\
\text { E }\end{array}$ & $\begin{array}{c}\text { All } \\
\text { sites }\end{array}$ \\
\hline$\%$ D-M-P assemblage & $96.9 \pm 2$ & $99.4 \pm 0.5$ & $98.4 \pm 1.8$ & $88.4 \pm 4.6$ & $66 \pm 14.1$ & $15.9 \pm 1.8$ & $85.9 \pm 26$ \\
\hline Diploria spp. (\%) & $72.2 \pm 3$ & $73 \pm 3.4$ & $72.7 \pm 3.1$ & $29.8 \pm 18$ & $50.8 \pm 9.1$ & $2.1 \pm 0.1$ & $50.5 \pm 28.6$ \\
\hline D. strigosa $(\%)$ & $41 \pm 1.2$ & $54.3 \pm 4.1$ & $49 \pm 7.5$ & $18.9 \pm 17$ & $5.6 \pm 4$ & $0.9 \pm 0.4$ & $33.6 \pm 21.4$ \\
\hline D. strig.:D. lab. (ratio) & $1.42 \pm 0.03$ & $3.42 \pm 1.04$ & $2.62 \pm 1.29$ & $2.20 \pm 1.27$ & $0.22 \pm 0.13$ & - & $2.39 \pm 1.25$ \\
\hline \multicolumn{8}{|l|}{$\%$ of hard coral cover } \\
\hline Diploria labyrinthiformis & $31.1 \pm 2$ & $18.7 \pm 3.1$ & $23.6 \pm 7$ & $10.9 \pm 5.2$ & $45.2 \pm 9$ & $1.2 \pm 0.5$ & $16.9 \pm 10.1$ \\
\hline Diploria strigosa & $41 \pm 1.2$ & $54.3 \pm 4.1$ & $49 \pm 7.5$ & $18.9 \pm 17$ & $5.6 \pm 4$ & $0.9 \pm 0.4$ & $33.6 \pm 21.4$ \\
\hline Montastraea cavernosa & $2 \pm 1.4$ & $5.3 \pm 1.9$ & $4 \pm 2.4$ & $11.2 \pm 10.2$ & $0.5 \pm 1$ & $0.1 \pm 0.1$ & $6 \pm 7$ \\
\hline Montastraea franksi & $13.7 \pm 5.3$ & $16.1 \pm 4.6$ & $15.1 \pm 4.8$ & $38.5 \pm 20.1$ & $2.8 \pm 2.1$ & $2.7 \pm 0.2$ & $21.5 \pm 17.3$ \\
\hline Porites astreoides & $9.1 \pm 5$ & $5 \pm 1.8$ & $6.6 \pm 3.8$ & $8.8 \pm 3.5$ & $12 \pm 7.4$ & $11 \pm 1.6$ & $7.9 \pm 3.7$ \\
\hline Madracis decactis & $0 \pm 0$ & $0.1 \pm 0.2$ & $0 \pm 0.1$ & $1.5 \pm 2.2$ & $8 \pm 4.2$ & $5.1 \pm 1.2$ & $1.1 \pm 2$ \\
\hline Madracis mirabilis & $0 \pm 0$ & $0 \pm 0$ & $0 \pm 0$ & $1.1 \pm 1.9$ & $10.9 \pm 4.9$ & $43.6 \pm 5.9$ & $5.2 \pm 14.1$ \\
\hline Millepora alcicornis & $2.8 \pm 2$ & $0.3 \pm 0.4$ & $1.3 \pm 1.7$ & $7.4 \pm 5.4$ & $2.1 \pm 2.2$ & $30.9 \pm 2.9$ & $6.6 \pm 9.8$ \\
\hline \multicolumn{8}{|l|}{ Benthic category cover } \\
\hline Hard corals & $25.0 \pm 3.5$ & $57.7 \pm 6.6$ & $44.6 \pm 17.7$ & $17.2 \pm 7.5$ & $4.9 \pm 1.2$ & $21.7 \pm 3.8$ & $32.9 \pm 19.1$ \\
\hline Gorgonians & $8.7 \pm 2.2$ & $4.1 \pm 2.3$ & $5.9 \pm 3.2$ & $3.0 \pm 1.8$ & $5.3 \pm 3.3$ & $1.4 \pm 0.1$ & $4.4 \pm 3.1$ \\
\hline Zoanthids & $0.0 \pm 0.0$ & $0.3 \pm 0.5$ & $0.2 \pm 0.4$ & $0.2 \pm 0.3$ & $0.2 \pm 0.1$ & $0.0 \pm 0.0$ & $0.2 \pm 0.4$ \\
\hline Sponges & $0.1 \pm 0.2$ & $0.1 \pm 0.1$ & $0.1 \pm 0.1$ & $2.2 \pm 1.5$ & $1.3 \pm 0.5$ & $3.8 \pm 1.7$ & $1.2 \pm 1.6$ \\
\hline $\begin{array}{l}\text { Anemones/Ascidians/ } \\
\text { Corallimorphs }\end{array}$ & $0.1 \pm 0.1$ & $0.3 \pm 0.2$ & $0.2 \pm 0.2$ & $0.1 \pm 0.2$ & $0.3 \pm 0.1$ & $0.1 \pm 0.0$ & $0.2 \pm 0.2$ \\
\hline Macroalgae & $22.5 \pm 13.2$ & $11.5 \pm 7.3$ & $15.9 \pm 11.0$ & $11.6 \pm 4.0$ & $25.1 \pm 19.9$ & $33.9 \pm 0.8$ & $16.4 \pm 10.6$ \\
\hline Turf algae & $38.5 \pm 7.9$ & $24.0 \pm 5.9$ & $29.8 \pm 9.8$ & $47.1 \pm 9.4$ & $50.6 \pm 16.9$ & $22.1 \pm 0.5$ & $34.7 \pm 12.8$ \\
\hline Coralline algae & $1.2 \pm 0.6$ & $0.9 \pm 0.3$ & $1.0 \pm 0.4$ & $0.0 \pm 0.0$ & $0.0 \pm 0.0$ & $0.7 \pm 0.1$ & $0.6 \pm 0.6$ \\
\hline Abiotic & $4.0 \pm 5.7$ & $1.2 \pm 0.6$ & $2.3 \pm 3.6$ & $18.6 \pm 3.7$ & $12.3 \pm 1.8$ & $16.3 \pm 2.5$ & $9.3 \pm 8.8$ \\
\hline
\end{tabular}



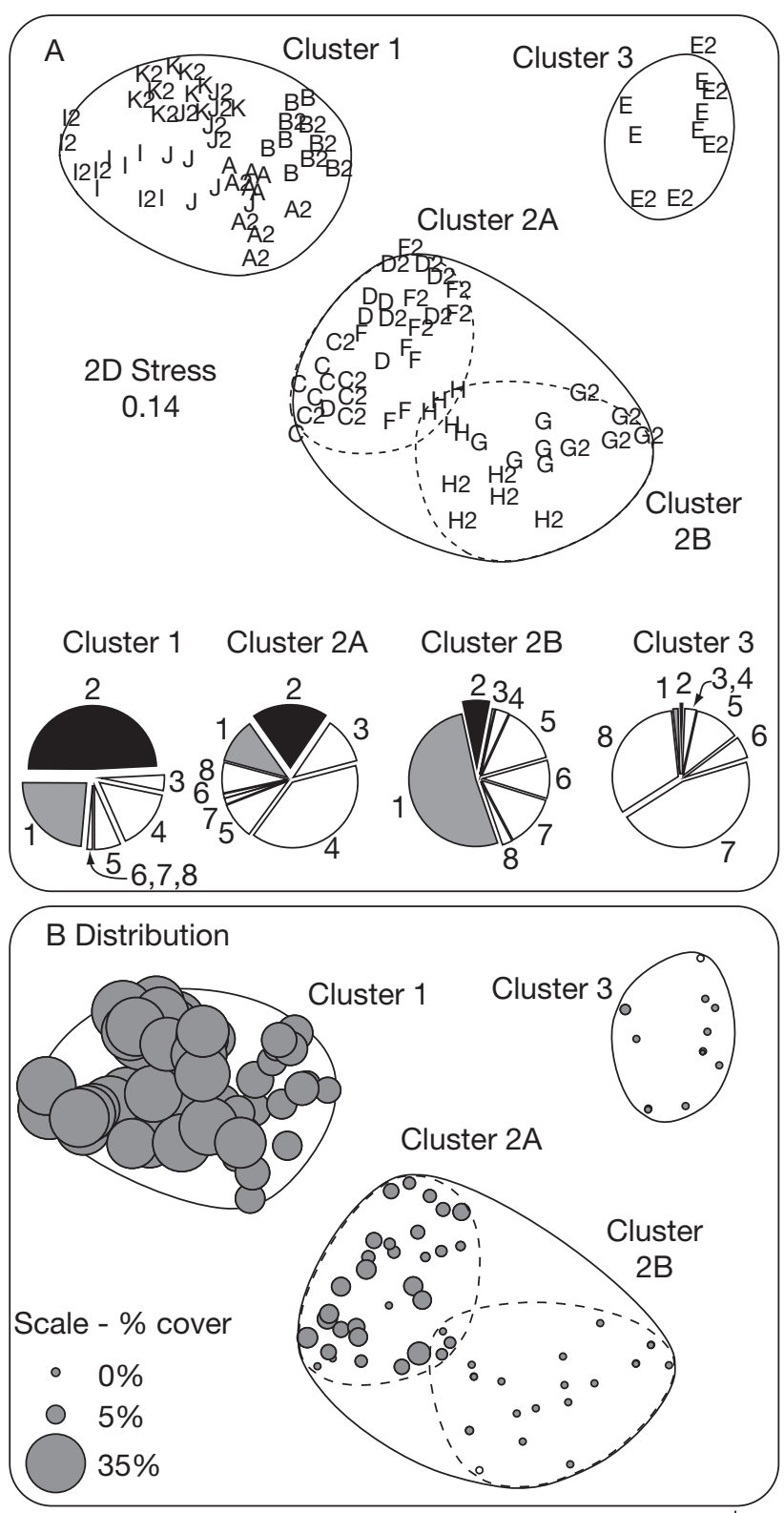

(C) BBD prevalence

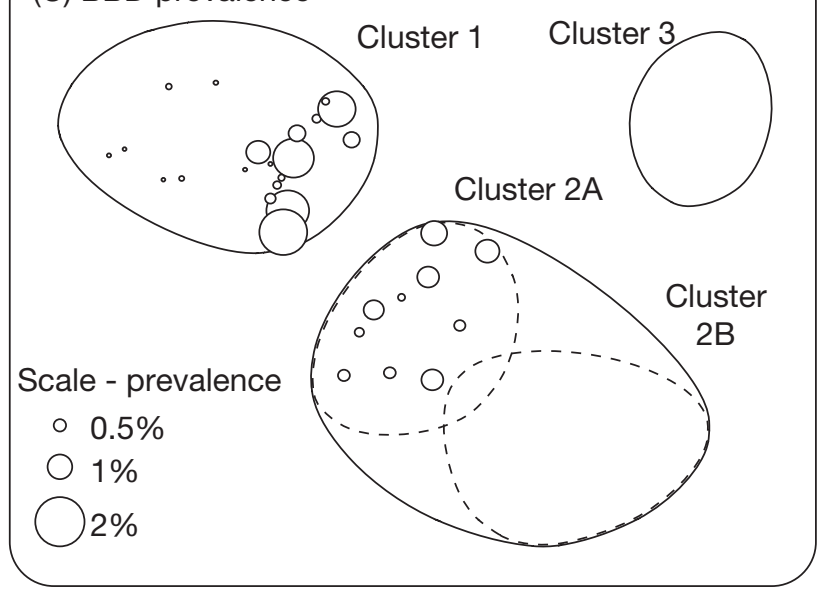

the 2 Diploria species collectively make up $75 \%$ of the hard coral cover, and D. strigosa makes up $50 \%$ of the coral cover (see pie-charts in Fig. 2A). The ratio of $D$. strigosa to $D$. labyrinthiformis varies from 1.42:1 on the rim reef to $3.42: 1$ on the main terrace reef (Table 1).

The results from the 2005 surveys can be compared to similar studies conducted on the main terrace and rim reef in the 1980s (see Dodge et al. 1982, Logan 1988). Although the exact location of the earlier surveys are unknown, Fig. 3 shows that for the Diploria spp, Montastraea spp. and Porites astreoides, the present day distribution patterns are essentially the same as in the 1980s, both for the main terrace reef (Fig. 3A) and outer rim reef (Fig. 3B) and in terms of the relative coral cover (\%) and absolute coral cover (Fig. 3A,B insets, Table 1).

\section{Hydrological studies}

Currents at the sewage outfall site were typically $<15 \mathrm{~cm} \mathrm{~s}^{-1}(\sim 0.3$ knots, see Fig. S1A in the supplement at www.int-res.com/articles/suppl/m462p079 _supp.pdf) over the 2 deployments, although for short periods, values exceeded $20 \mathrm{~cm} \mathrm{~s}^{-1}$, with a maximal value of $30 \mathrm{~cm} \mathrm{~s}^{-1}$ ( 0.6 knots) during the second deployment. Currents at the outfall flow in predominantly SW-NE directions, flooding to the SW and ebbing to the NE (see Fig. S1B in the supplement). Data on current and wind speed and direction for the 2 deployments are also included in the supplemental material (Fig. S1A-D). Observation of the flows as a scatter plot for the 2 deployments show that the main axis of flow at the outfall site is from the SW (220 to $\left.230^{\circ}\right)$ to the NE $\left(40\right.$ to $50^{\circ}$; Fig. $\left.4 \mathrm{~A}\right)$. Further, it appears that flows in the NW and SE sector are not common,

Fig. 2. (A) MDS plots from Bray-Curtis similarities on square-root transformed abundance data (letters refer to individual transect lines at each of the sites shown in Fig. 1A). Clusters 1 to 3 and Sub-clusters 2A and 2B are defined using arbitrarily chosen similarity thresholds of $65 \%$ and $60 \%$ respectively based on dendrograms from group average clustering of the Bray-Curtis similarities. Pie charts: relative dominance of hard corals based on averages of cover, within each of the clusters of sites identified by the MDS analysis. 1: Diploria labyrinthiformis (grey shading), 2: D. strigosa (black shading), 3: Montastraea franksi, 4: Porites astreoides, 5: Madracis mirabilis, 6: Millepora alcicornis, 7: Montastraea cavernosa, 8: Madracis decactis, 9: Stephanocoenia michelinii, 10: Oculina spp., 11: Siderastrea radians, 12: Favia fragum. (B) MDS plot superimposed with the coverage $(\%)$ of $D$. strigosa or (C) BBD prevalence (\%) in D. strigosa 


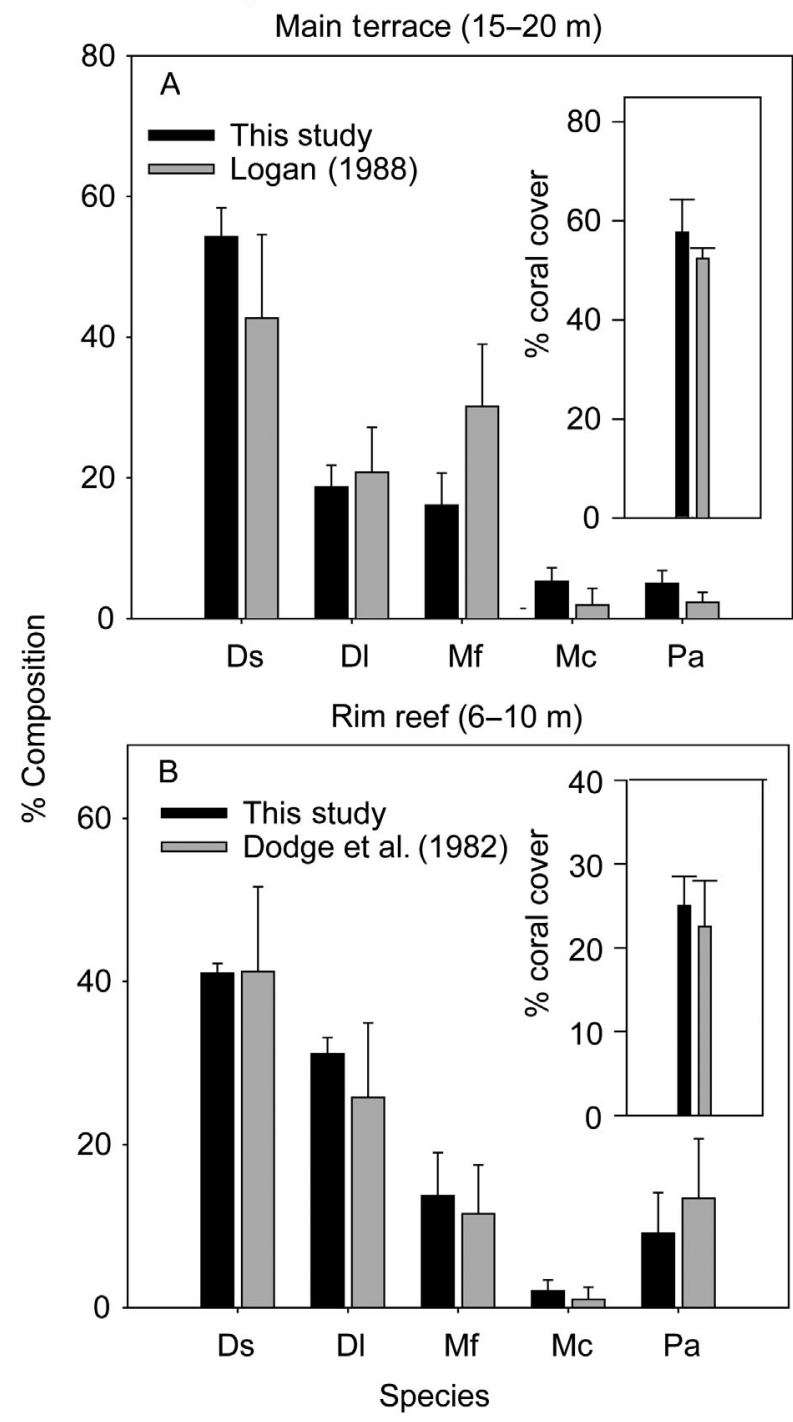

Fig. 3. Relative composition of the (A) main terrace reefs (Sites I, I2, J, J2, K, K2 in Fig. 1A) and (B) outer rim reef (Sites A, A2, B, B2 in Fig. 1A) compared with data from Dodge et al. (1982) and Logan (1988). Insets: absolute hard coral coverage (\% cover). Ds: Diploria strigosa, Dl: D. labyrinthiformis, Mf: Montastraea franksi, Mc: M. cavernosa, Pa: Porites astreoides

with only $8 \%$ and $2 \%$ of the total flows respectively, while $27 \%$ was to the NE and $63 \%$ to the SW sector. Overall, the weakly semi-diurnal characteristic resulted in a biased flow to the SW and a residual flow of $\sim 4.6 \mathrm{~cm} \mathrm{~s}^{-1}\left(\sim 4 \mathrm{~km} \mathrm{~d}^{-1}\right)$ over the hydrological observation period.

Drogues released on flooding tides moved predominantly in a SW direction irrespective of whether winds were onshore or offshore (Fig. 4B, Fig. S2B,D in the supplement). In one of these studies, conducted with a directly onshore wind, the surface drogue crossed the inner line of boiler reefs and
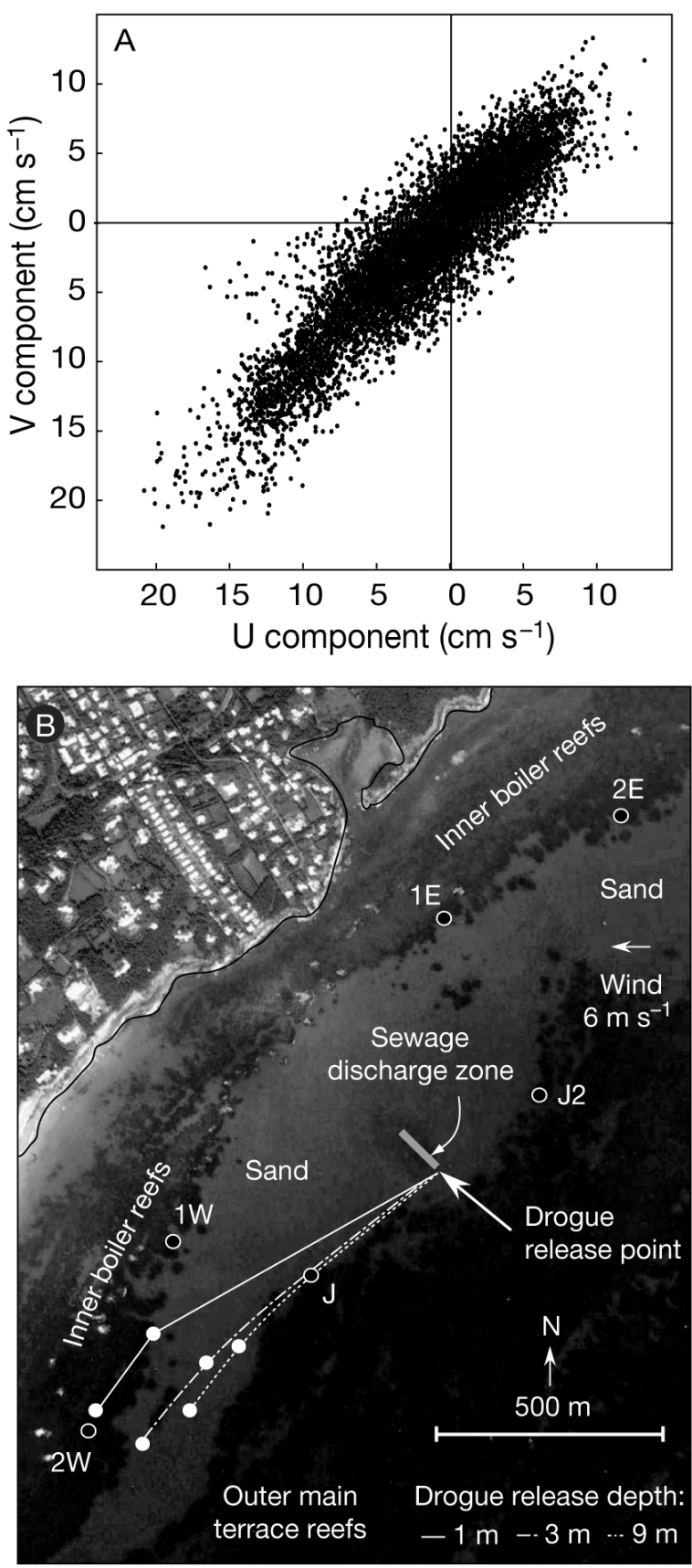

Fig. 4. (A) The distribution of flows at the Seabright Point sewage outfall decomposed into orthogonal velocity components $U$ (west-east direction, with values $>0$ indicating flow to the east) and V (south-north direction, with values $>0$ indicating flow to the north), where each point represents a single $10 \mathrm{~min}$ vector averaged observation whereby the speed is relative to the distance from the origin (see the supplement at www.int-res.com/articles/suppl/m462p079_supp. pdf for current speed and wind speed and direction). (B) Drogue tracking study, showing the drift of drogues deployed at 1, 3 and $9 \mathrm{~m}$ depth on a flooding tide with an onshore wind, relative to the various monitoring sites (see Fig. 1; see supplemental data for additional drogue deployments during different tidal phases and wind directions) 
reached the shoreline (Fig. S2B); however, in all other instances, the drogues moved in an approximately longshore direction, maintaining a SW trajectory. On the ebbing tide (i.e. Fig. S2C,E), the flow direction was usually in a NE or E direction, with the surface (1 $\mathrm{m}$ depth) drogues being more influenced by wind direction than the deeper drogues (3 and $9 \mathrm{~m}$ ) during an offshore wind (Fig. S2E).

Based on the hydrological studies, the videographic and disease survey sites were located east and west of the outfall on the closest main terrace reefs within the axis of flow of the sewage plume (see Figs. 1C \& 4B). These sites ( $\mathrm{J}$ and J2) were $\sim 302 \mathrm{~m}$ and $333 \mathrm{~m} \mathrm{NE}\left(58^{\circ}\right)$ and $\mathrm{SW}\left(225^{\circ}\right)$ respectively from the terminal diffuser of the outfall, although due to a series of risers before the terminal diffuser, the sewage is released in a $\sim 100 \mathrm{~m}$ discharge zone (see Fig. 4B). Ten additional coral disease monitoring sites were located on shallower (8 to $10 \mathrm{~m}$ depth) near shore reefs located between $\sim 0.5 \mathrm{~km}$ and $3.3 \mathrm{~km}$ east and west of the sewage outfall (see Fig. 1C).

Water sampling for fecal indicator bacteria was conducted on a flooding tide, and enterococci counts along the putative gradient ranged from $51 \mathrm{CFUs}$ $100 \mathrm{ml}^{-1}$ at Site J (300 m west of the outfall), to $11 \mathrm{CFUs} 100 \mathrm{ml}^{-1}$ at Site I, $\sim 6 \mathrm{~km}$ west of the outfall (Fig. 5). Enterococci counts at Site J2 (330 m east of the discharge zone) were $40 \mathrm{CFUs} 100 \mathrm{ml}^{-1}$, but all other sites east of the outfall were below the detection limits (Fig. 5). In additional water sampling immediately around the terminal diffuser in June 2008, values of 2300 and $1300 \mathrm{CFUs} 100 \mathrm{ml}^{-1}$ were recorded.

\section{Spatial patterns of BBD prevalence}

Between 2004 and 2008, a total of 355 incidences of BBD were observed in $\sim 160000$ corals surveyed.

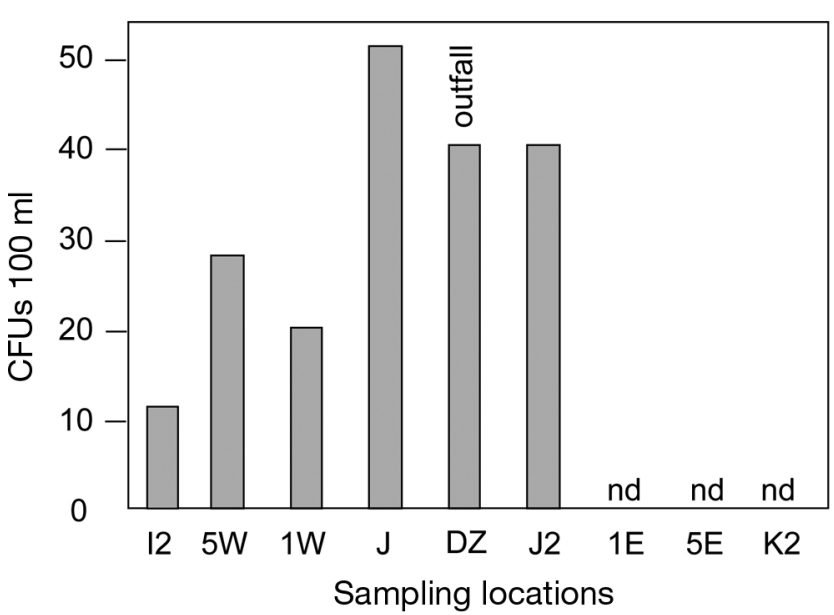

Fig. 5. Fecal indicator bacteria (gastrointestinal enterococci) counts as colony forming units (CFUs) per $100 \mathrm{ml}$ at 9 locations (see Fig. 1B,C) situated from 0.3 to $6 \mathrm{~km}$ east and west of the sewage outfall. DZ: samples collected close to the sewage outfall in the Discharge Zone (see Fig. 1C); nd: not detected

BBD was most prevalent in Diploria strigosa > Montastraea franksi $>$ M. cavernosa $=$ D. labyrinthiformis $>$ Porites astreoides and the hydrocoral Millepora alcicornis (Table 2). Overwhelmingly, BBD was most prevalent in the symmetrical brain coral $D$. strigosa (316 incidences), and because it is the most abundant coral in Bermuda, with a wide distribution across the platform (Table 1, Fig. 2B), spatial patterns of BBD prevalence and proximity to the sewage outfall were examined mostly in this species.

BBD was not recorded on any Diploria strigosa colonies on the nearshore patch reef sites E and E2, where there was a low abundance of $D$. strigosa (Table 1) and where typically $<10$ colonies were encountered each year at each site. BBD was also not recorded at Sites G, G2, H and H2, where there was also a low abundance of $D$. strigosa (Table 1 ) and typically $\sim 30$ colonies were examined each year at each

Table 2. Black band disease (BBD) prevalence in 5 coral species in Bermuda from 2004 to 2008. n: number of recorded BBD infections; total: total number of coral colonies examined

\begin{tabular}{|c|c|c|c|c|c|c|c|c|c|c|c|c|c|c|c|}
\hline \multirow[t]{2}{*}{ Year } & \multicolumn{3}{|c|}{$\begin{array}{l}\text { Diploria } \\
\text { strigosa }\end{array}$} & \multicolumn{3}{|c|}{$\begin{array}{c}\text { Diploria } \\
\text { labyrinthiformis }\end{array}$} & \multicolumn{3}{|c|}{$\begin{array}{c}\text { Montastraea } \\
\text { cavernosa }\end{array}$} & \multicolumn{3}{|c|}{$\begin{array}{l}\text { Montastraea } \\
\text { franksi }\end{array}$} & \multicolumn{3}{|c|}{$\begin{array}{l}\text { Porites } \\
\text { astreoides }\end{array}$} \\
\hline & $\mathrm{n}$ & Total & $\%$ & $\mathrm{n}$ & Total & $\%$ & $\mathrm{n}$ & Total & $\%$ & $\mathrm{n}$ & Total & $\%$ & $\mathrm{n}$ & Total & $\%$ \\
\hline 2004 & 107 & 11765 & 0.91 & 1 & 5460 & 0.02 & 0 & 1135 & 0.00 & 10 & 1689 & 0.59 & 0 & 10612 & 0.00 \\
\hline 2005 & 92 & 15032 & 0.59 & 0 & 6873 & 0.00 & 1 & 1978 & 0.05 & 11 & 2187 & 0.50 & 1 & 13496 & 0.01 \\
\hline 2006 & 60 & 16998 & 0.35 & 1 & 7858 & 0.01 & 2 & 2124 & 0.09 & 5 & 2434 & 0.21 & 0 & 15297 & 0.00 \\
\hline 2007 & 39 & 17196 & 0.23 & 1 & 8059 & 0.01 & 0 & 2101 & 0.00 & 5 & 2307 & 0.22 & & t surveye & \\
\hline 2008 & 22 & 14116 & 0.15 & 0 & 6567 & 0.00 & 0 & 1528 & 0.00 & 2 & 1811 & 0.11 & & & \\
\hline Totals: & 316 & 75107 & 0.44 & 3 & 31812 & 0.01 & 3 & 8865 & 0.03 & 33 & 10428 & 0.32 & 1 & 39405 & 0.00 \\
\hline
\end{tabular}


site. On the outer rim reef (i.e. Sites $\mathrm{A}, \mathrm{A} 2$, B and B2 in Fig. $1 \mathrm{~A}, \mathrm{~B}$ ) and on the deeper main terrace reefs (Sites I, I2, J, J2, K and K2 in Fig. 1A,B), D. strigosa dominates, and typically between 400 and 1000 colonies of $D$. strigosa were examined at each site each year. On the patch reefs of Cluster 2A (in Fig. 2A, i.e. Locations C, C2, D, D2, F and F2 in Fig. 1A,B), Diploria species were less abundant (see Table 1), but between 70 and 200 colonies were examined at each site each year. Between 2004 and 2008, BBD prevalence in D. strigosa ranged from 0.0 to $2.8 \%$ (Fig. 6 A) on the outer rim reef sites, nearly an order of magnitude higher than on the main terrace, where the BBD prevalence ranged from 0 to $0.8 \%$, Fig. $6 \mathrm{~A}$ ).

In 2003 , the maximum average daily seawater temperatures on the outer rim reef (Site A in Fig. 1A,B) was $29.9^{\circ} \mathrm{C}$ and exceeded $28.5^{\circ} \mathrm{C}$ on $31 \mathrm{~d}$ (Fig. $7 \mathrm{~A}, \mathrm{~B}$ ). Water temperatures in 2004 and 2005 were higher than those recorded in the summers of 2006, 2007 and 2008 , exceeding $28.5^{\circ} \mathrm{C}$ on $15 \mathrm{~d}(2004)$ and $29 \mathrm{~d}$ (2005) compared with $3 \mathrm{~d}$ (2006), $9 \mathrm{~d}$ (2007) and $5 \mathrm{~d}$ (2008; Fig. 7B).

Fig. 2 integrates the results from the videographic surveys and analysis of community structure across the platform, the analysis of the hard coral composition and the surveys of BBD prevalence in Diploria strigosa (using data from 2005). The plot shows the MDS ordinations of community composition superimposed with bubble plots whereby the size of each bubble reflects either the coverage of $D$. strigosa (Fig. 2B) or BBD prevalence (Fig. 2C). Thus, the highest density of $D$. strigosa is on the deeper (15 to $18 \mathrm{~m}$ depth) main terrace sites (I, I2, J. J2, K and K2 in Fig. $1 \mathrm{~A}, \mathrm{~B})$ in Cluster 1 , followed by the shallower (8 to $10 \mathrm{~m}$ depth) rim reef sites $(\mathrm{A}, \mathrm{A} 2, \mathrm{~B}$ and $\mathrm{B} 2$ in Fig. $1 \mathrm{~A}, \mathrm{~B})$ and then the shallow ( $5 \mathrm{~m}$ depth) patch reef sites $(C, C 2, D, D 2, F$ and $F 2$ in Fig. $1 A, B$; Fig. 2B). BBD prevalence in $D$. strigosa is highest on the outer rim reefs (part of Cluster 1) and lagoonal patch reefs (Cluster 2A), with very low prevalence on the deeper terrace reefs (Fig. 2B), and no recorded BBD incidences in the inshore and near shore patch reefs of Clusters 2B and 3 (Fig. 2C).

Along the contamination gradient on either side of the Seabright Point (i.e. $\sim 500 \mathrm{~m}$ and up to $3.3 \mathrm{~km}$

Fig. 6. (A) Black band disease (BBD) prevalence in Diploria strigosa in different physiographic reef zones in Bermuda (see Fig. 1A). (B) BBD at 5 nearshore reefs between 0.3 and $3.3 \mathrm{~km}$ east and west of the sewage outfall (see Fig. 1B). (C) BBD prevalence plotted against distance (either east or west) from the sewage outfall. All disease surveys were conducted between mid-July and mid-September each year
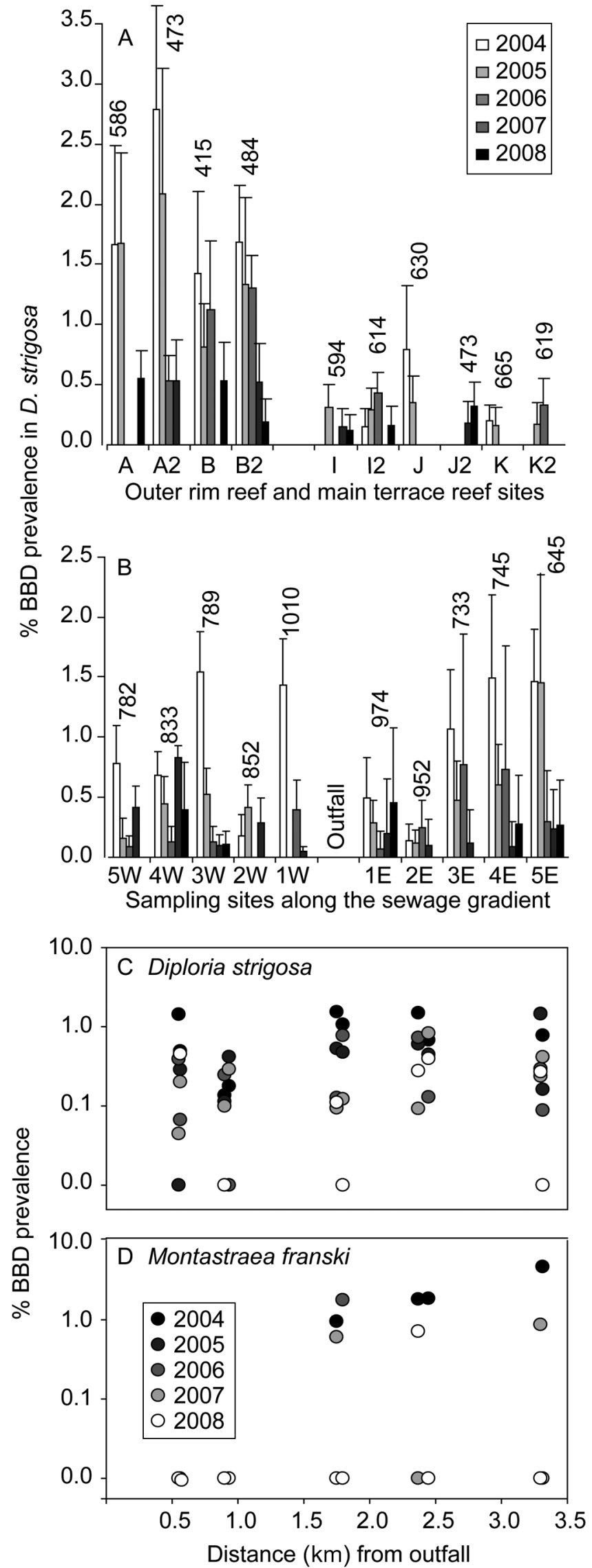

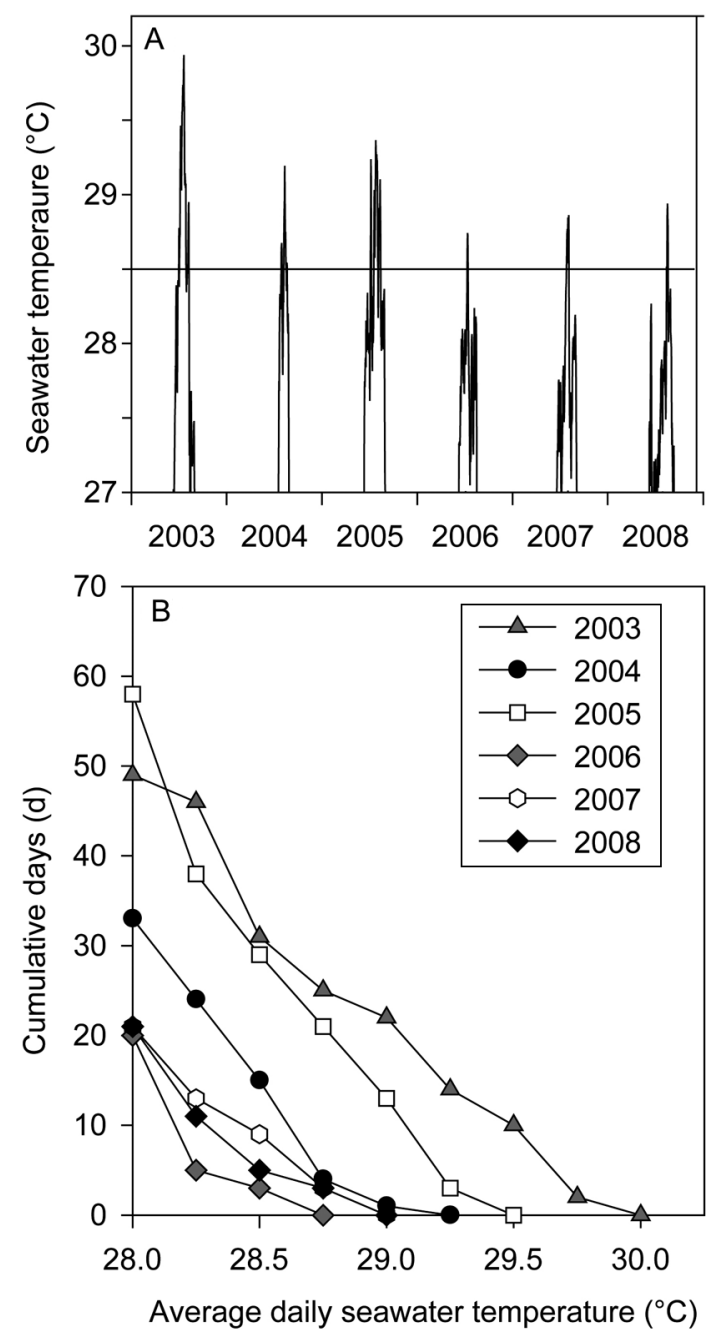

Fig. 7. (A) Average daily seawater temperature $\left({ }^{\circ} \mathrm{C}\right)$ recorded at 8 to $10 \mathrm{~m}$ depth on the outer rim reef (Site $\mathrm{A} 2$ in Fig. 1A) over the study period. (B) The number of days that average daily seawater temperatures at 8 to $10 \mathrm{~m}$ depth on the outer rim reef (Site A2 in Fig. 1A) exceeded a given temperature level (range: 28 to $30^{\circ} \mathrm{C}$ )

either side of the outfall, see Fig. 1C), BBD prevalence in Diploria strigosa was very low throughout the $5 \mathrm{yr}$ study period, ranging from $0 \%$ to a maximum of $1.5 \%$ (at Sites $3 \mathrm{~W}, 4 \mathrm{E}$ and 5E in 2004; Fig. 6B,C). A GLM analysis indicated that the relationship between BBD prevalence in $D$. strigosa and distance from the outfall was not significantly different between the east and west ( $p$-value $=0.16)$, and thus, the model was fitted without the interaction term. The new model (fitted with only distance) indicates that there is a significant relationship with distance $(p$-value $=0.0272)$ and that BBD prevalence increases by a factor of 1.37 with each unit of distance.
There were only 33 incidences of BBD recorded in Montastraea franksi over the study period, in contrast to the 316 incidences in D. strigosa (Table 1). No BBD infections were recorded at the sites closest to the outfall (Sites 1W, 2W, 1E and 2E) over the $5 \mathrm{yr}$ survey, but some incidences were observed at the sites $1.75,2.5$ and $3.3 \mathrm{~km}$ east and west of the outfall in some years (Fig. 6D). The highest BBD prevalence level in $M$. franksi (4.8\%) was recorded at Site 5W, $3.2 \mathrm{~km}$ west of the outfall in 2004 (Fig. 6D).

\section{DISCUSSION}

The relationship between disease prevalence and anthropogenic or pollution effects is one of the least understood areas of coral disease, and the relationship will ultimately be resolved by laboratory experiments, ecological surveys in relation to individual pollution sources and large-scale surveys of prevalence relative to pristine and developed catchments (see Page \& Willis 2006). With the caveat that our present study is limited mostly to 1 species (Diploria strigosa), overall, there was no obvious relationship between $\mathrm{BBD}$ prevalence and proximity to a major sewage outfall. BBD prevalence levels on reefs close to the outfall were consistently lower (over the $5 \mathrm{yr}$ study period) than on Bermuda's outer rim reef, where water quality is exceptional and nutrient concentrations are often indistinguishable from Sargasso Sea water of the oligotrophic North Atlantic gyre (Morris et al. 1977).

Bermuda's reefs are dominated by massive, hemispherical, high-relief coral species from the DiploriaMontastraea-Porites coral assemblage and notably lack branching acroporid species. In the present study, BBD was observed in all of the Diploria spp., Montastraea spp. and Porites spp. that make up the assemblage, but prevalence levels were typically low (see also Weil 2004). BBD prevalence levels were only high enough in 1 species, $D$. strigosa, to allow spatial and temporal patterns to be examined, and because this species is the most common coral in Bermuda (with a wide distribution across the platform), the relationship between BBD prevalence and proximity to the sewage was analyzed mostly with $D$. strigosa.

\section{Sewage pollution and BBD prevalence}

Hydrological investigations around the sewage outfall, involving a combination of lagrangian and 
eulerian current studies, showed complex flow patterns, with weakly semi-diurnal tidal components often fluctuating on diurnal periods. Overall, the primary axis of flow was identified as a longshore current (in a NE/SW direction), and the inequality of the semi-diurnal characteristics partly results in a biased flow to the SW. This residual flow was also consequence of wind-driven patterns, where the tide, although rising and falling, occasionally ebbed and flooded in the same direction (i.e. to the SW sector, see also the supplement at www.int-res.com/articles/suppl/m462p079_supp.pdf).

The detailed hydrological studies were needed in the present study to guide the placement of monitoring sites for BBD prevalence, which were eventually located along the primary axis of flow identified from the current meter deployments. The putative gradient was examined using water sampling and counting of fecal indicator bacteria (gastrointestinal enterococci). The sampling was conducted during a calm sea-state and a flooding tide and showed elevated CFUs primarily west of the outfall rather than east and higher levels closer to the outfall than in more distant locations. These results are consistent with the finding of the hydrological studies and confirm that the sampling sites were located along a sewage exposure gradient associated with the outfall.

It was expected that if there was a relationship between BBD and sewage pollution, the prevalence would be highest on reefs closest to the outfall (which are regularly inundated by sewage) and decrease with increasing distance from the outfall. Contrary to these expectations, BBD prevalence in Diploria strigosa was higher further away from the outfall. The overall BBD prevalence in D. strigosa on reefs exposed to sewage was lower than on the northern rim reef 10 to $15 \mathrm{~km}$ from the nearest coastline. Although only 33 incidences of BBD were recorded in Montastraea franksi (in 10500 colonies examined), no incidences were ever recorded at the sites closest to the outfall over the duration of the $5 \mathrm{yr}$ study. This pattern is also consistent with there being no relationship between BBD prevalence and sewage exposure in $M$. franksi.

\section{Spatial patterns of BBD prevalence}

Diploria strigosa abundance was very low on some of the nearshore patch reefs and the inshore reefs, and BBD infections were rarely observed there. On the shallow ( $<10 \mathrm{~m}$ depth) outer rim reef and patch reefs of the lagoon, BBD prevalence levels were higher, and D. strigosa abundance was much higher. While this pattern suggests a positive relationship between abundance and BBD prevalence, the highest D. strigosa abundance in Bermuda was found on the deeper main terrace reef system, where BBD prevalence was very low. Light has been suggested as a factor controlling BBD progression (Kuta \& Richardson 2002, Boyett et al. 2007), and on hemispherical or conical species, such as D. strigosa, BBD usually appears on flat, sunlight-exposed surfaces (Antonius 1976). This observation is consistent with multiple reports of higher BBD prevalence in shallow as opposed to deep water (Rützler \& Santavy 1983, Taylor 1983, Antonius 1985). Thus, the low BBD prevalence on the main terrace could be the result of the light requirement of the photoautotrophic cyanobacteria of the BBD consortium (Kuta \& Richardson 2002, Richardson \& Kuta 2003). The pattern could also be due to absence of a putative BBD disease vector and also to water temperatures, which are usually cooler on the terrace reef for most of the summer (R. Jones unpubl. data).

Over the study period, the BBD prevalence in Diploria strigosa on the outer rim reef systematically decreased from a maximum value (per site) of $2.8 \%$ in 2004 to $0.6 \%$ in 2008. In August 2003, and during a coral bleaching event, BBD prevalence levels were as high as $\sim 3.9 \%$ (at Site $A_{\text {; }}$ see Fig. $1 B_{\text {; }}$ see Jones 2004). BBD abundance has a strong positive correlation with temperature in field studies (e.g. Bruckner et al. 1997, Borger \& Steiner 2005, Voss \& Richardson 2006). In 2003, water temperatures (recorded by in situ temperature loggers on the reef) were unusually high, both in terms of absolute maximum temperature and also in terms of cumulative temperature, i.e. the number of days in which average daily seawater temperatures exceeded a given level. The summers of 2004 and 2005 were also much warmer than 2006, 2007 and 2008, and the general decrease in the BBD prevalence over the study period could be related to water temperatures. This could be either directly by increasing the progression and activity of pathogen, or as noted by Boyett et al. (2007), by change in other factors that vary concurrently with water temperature.

One of the more surprising results of the present study was the near absence of BBD in Diploria labyrinthiformis compared with $D$. strigosa. Over the study period, there were only 3 recorded incidences of BBD in just over 30000 colonies of D. labyrinthiformis examined, compared to $>300$ incidences in just over 75000 colonies of D. strigosa. Antonius (1981) indicated that D. strigosa was more BBD susceptible than D. labyrinthiformis (see also Weil 2004), but in their initial description of the disease in 
Bermuda, Garrett \& Ducklow (1975) made no distinction between the 2 species, citing a prevalence level of 0.5 to $1 \%$ for both. The 2 species are within the same genus and have broadly similar spatial and depth-related distributional patterns in Bermuda (Fricke \& Meischner 1985, Logan 1988), and it is not clear why $D$. labyrinthiformis is almost immune to BBD infection.

Recent laboratory studies have shown that Diploria labyrinthiformis in Bermuda will develop the symptoms of BBD when an inoculum (from a colony of D. strigosa) is introduced into a surface lesion (Kuehl et al. 2011). Experimentally manipulating combinations of light and temperature will also change the rate of progression of BBD across the surface of inoculated D. labyrinthiformis colonies in the same way as on D. strigosa colonies (Kuehl et al. 2011). This suggests that the source of the differential susceptibility to BBD between the 2 species is related to factors before infections are established. Interestingly, in their recent comparative study of sexual reproduction in the genus Diploria (D. strigosa, D. clivosa and D. labyrinthiformis), Weil \& Vargas (2010) noted that the morphological and micro-morphological characteristics of $D$. labyrinthiformis appear significantly different to the other species examined, with $D$. labyrinthiformis appearing similar to other taxonomically distinct species (i.e. Dendrogyra). Weil \& Vargas (2010) recommended a reassessment of its taxonomic position, and it follows that the difference in susceptibility of $D$. labyrinthiformis and D. strigosa to BBD infection in Bermuda may be phylogenetic in origin.

\section{Ecological significance of BBD in Bermuda}

Bermuda's reefs are some of the most northerly and most isolated in the world. With a very high population density and with already clear evidence of local pollution (Jones 2007, 2010, 2011, Jones et al. 2011), they are in a high threat category. Some of the earliest coral reef surveys ever undertaken were conducted on Bermuda's reefs in the 1980s (see Dodge et al. 1982, Logan 1988). Although the exact locations (i.e. position within individual reefs) of these surveys are unknown, the present day cover and composition in the major physiographic reef zones in which the surveys were conducted have essentially remained unchanged. Thus, despite the threats, Bermuda's reefs have evidently fared quite well over the last quarter century compared with those of the wider Caribbean (see Gardner et al. 2003).
BBD poses a significant threat to Bermuda's reefs because it is usually always associated with tissue loss, i.e. with partial coral mortality (Edmunds 1991), and was observed on all 5 of the key coral species in Bermuda responsible for reef formation (i.e. the Diploria-Montastraea-Porites species assemblage). These species have massive growth forms, are resistant to hurricane and storm damage and have yet to suffer appreciable levels of mortality during bleaching events (Cook et al. 1993), and consequently, BBD infection constitutes one of the most important potential sources of natural mortality.

Offsetting the overall risks posed by BBD infection to the corals of Bermuda is the fact that prevalence levels are currently low (see Weil 2004) and largely confined to 1 species, Diploria strigosa. Furthermore, $\mathrm{BBD}$ infection is very low on Bermuda's main terrace reef system. This geomorphologcial feature (the '10 fathom terrace' of Stoddart 1969) is very well developed in Bermuda (Stanley \& Swift 1968). Located at 14 to $18 \mathrm{~m}$ depth and extending from 1 to $7 \mathrm{~km}$ seaward of the rim to the outer platform margin, the terrace has a high coral cover (up to $70 \%$ in the present surveys) and forms the bulk of Bermuda's reef. It can effectively be considered a refugium from BBD infection for the Diploria-Montastraea-Porites species assemblage.

It is interesting to note that on the terrace, the ratio of Diploria strigosa:D. labyrinthiformis is $\sim 3.5: 1$, whereas on the outer rim reef (where BBD infections are most common in $D$. strigosa but not in $D$. labyrinthifomis), the ratio is much less (i.e. $<1.5: 1$ ). It is rare to find large ( 0.5 to $1 \mathrm{~m}$ diameter) colonies of $D$. strigosa on the outer rim reef without any patches of partial mortality consistent with a prior BBD infection (evidenced by smooth edged circular or elliptical patches of partial mortality, mainly on the tops and sides of colonies; see Garrett \& Ducklow 1975). We speculate whether the susceptibility of $D$. strigosa to BBD infection and comparative immunity in $D$. labyrinthiformis is decreasing its competitive ability on the shallow outer rim reef and that this is an ecological signature of the effect of BBD in structuring Bermuda's reef.

In conclusion, in this $5 \mathrm{yr}$ study of BBD prevalence in corals at multiple locations in Bermuda, including sites in different reef zones and along a confirmed sewage contamination gradient, there was no evidence for elevated BBD prevalence in Diploria strigosa in relation to sewage pollution. Overall, BBD prevalence levels were higher in areas of generally exceptional water quality characteristics of the oligotrophic North Atlantic gyre, characterized by the Sargasso Sea. 
Acknowledgements. Funding was provided by the Bermuda Government Ministry of the Environment, Bermuda Government Department of Health and Bermuda Institute of Ocean Sciences (BIOS). The views and opinions expressed in this paper are those of the authors.

\section{LITERATURE CITED}

Antonius A (1976) New observations on coral destruction in reefs. Proc Assoc Isl Mar Lab Caribb, Mayagüez 10:17

Antonius A (1981) The 'band' diseases in coral reefs. Proc 4th Int Coral Reef Symp, Manila 2:7-14

Antonius A (1985) Coral disease in the Indo-Pacific: a first record. PSZNI Mar Ecol 6:197-218

Aronson RB, Precht WF (2001) White-band disease and the changing face of Caribbean coral reefs. Hydrobiologia 460:25-38

Borger JL, Steiner SCC (2005) The spatial and temporal dynamics of coral diseases in Dominica, West Indies. Bull Mar Sci 77:137-154

Boyett HV, Bourne DG, Willis BL (2007) Elevated temperature and light enhance progression of black band disease on staghorn corals of the Great Barrier Reef. Mar Biol 151:1711-1720

Bruckner AW, Bruckner RJ, Williams EH (1997) Spread of a black-band disease epizootic through the coral reef system in St. Ann's Bay, Jamaica. Bull Mar Sci 61:919-928

Burke L, Maidens J (2004) Reefs at risk in the Caribbean. World Resources Institute (WRI), Washington, DC

Cook CB, Dodge RE, Smith SR (1993) Fifty years of impacts on coral reefs in Bermuda. In: Ginsburg R (ed) Global aspects of coral reefs: health, hazards and history. Rosenstiel School of Marine and Atmospheric Sciences, University of Miami, FL, p 160-166.

Dodge RE, Logan A, Antonius A (1982) Quantitative reef assessment studies in Bermuda: a comparison of methods and preliminary results. Bull Mar Sci 32:745-760

Edmunds PJ (1991) Extent and effect of black band disease on a Caribbean reefs. Coral Reefs 10:161-165

> Folke C, Carpenter S, Walker B, Scheffer M, Elmqvist T, Gunderson L, Holling CS (2004) Regime shifts, resilience, and biodiversity in ecosystem management. Annu Rev Ecol Evol Syst 35:557-581

Frias-Lopez J, Klaus JS, Bonheyo GT, Fouke BW (2004) Bacterial community associated with black band disease in corals. Appl Environ Microbiol 70:5955-5962

Fricke H, Meischner D (1985) Depth limits of Bermudan scleractinian corals: a submersible survey. Mar Biol 88: 175-187

> Gardner TA, Côté IM, Gill JA, Grant A, Watkinson AR (2003) Long-term region-wide declines in Caribbean coral reefs. Science 301:958-960

Garrett P, Ducklow P (1975) Coral disease in Bermuda. Nature 253:349-350

Goreau TJ, Cervino J, Goreau M, Hayes R and others (1998) Rapid spread of diseases in Caribbean coral reefs. Rev Biol Trop 46 (Suppl 5):157-171

Hayes RL, Goreau NI (1998) The significance of emerging diseases in the tropical coral reef ecosystem. Rev Biol Trop 46(Suppl 5):173-185

Hughes TP (1994) Catastrophes, phase-shifts, and largescale degradation of a Caribbean coral reef. Science 265: 1547-1551

Hughes TP, Baird AH, Bellwood DR, Card M and others
(2003) Climate change, human impacts, and the resilience of coral reefs. Science 301:929-933

Jones RJ (2004) Marine Environmental Program 2003/2004 annual report to the Ministry of the Environment, Department of Environmental Protection, Bermuda

Jones RJ (2007) Chemical contamination of a coral reef by the grounding of a cruise ship in Bermuda. Mar Pollut Bull 54:905-911

> Jones RJ (2010) Environmental contamination associated with a marine landfill ('seafill') beside a coral reef. Mar Pollut Bull 60:1993-2006

> Jones RJ (2011) Spatial patterns of chemical contamination (metals, PAHs, PCBs, PCDDs/PCDFS) in sediments of a non-industrialized but densely populated coral atoll/ small island state (Bermuda). Mar Pollut Bull 62: 1362-1376

Jones R, Parsons R, Watkinson E, Kendell D (2011) Sewage contamination of a densely populated coral 'atoll' (Bermuda). Environ Monit Assess 179:309-324

Kaczmarsky LT, Draud M, Williams EH (2005) Is there a relationship between proximity to sewage effluent and the prevalence of coral disease? Caribb J Sci 41:124-137

> Kleypas JA, Buddemeier RW, Gattuso JP (2001) The future of coral reefs in an age of global change. Int J Earth Sci 90:426-437

Kohler KE, Gill SM (2006) Coral point count with Excel extensions (CPCe): a Visual Basic program for the determination of coral and substrate coverage using random point count methodology. Comput Geosci 32:1259-1269

> Kuehl K, Jones RJ, Gibbs D, Richardson L (2011) The roles of temperature and light in black band disease (BBD) progression on corals of the genus Diploria in Bermuda. J Invertebr Pathol 106:366-370

Kuta KG, Richardson LL (2002) Ecological aspects of black band disease of corals: relationships between disease incidence and environmental factors. Coral Reefs 21: 393-398

Logan A (1988) Holocene reefs of Bermuda. Sedimenta XI, Rosenstiel School of Marine and Atmospheric Science, University of Miami, FL, USA

Morris B, Barnes J, Brown F, Markham J (1977). The Bermuda marine environment. Berm Biol Stn Res Spec Publ 15:1-120

Page C, Willis B (2006) Distribution, host range and largescale spatial variability in black band disease prevalence on the Great Barrier Reef, Australia. Dis Aquat Org 69: $41-51$

Richardson LL (1998) Coral diseases: What is really known? Trends Ecol Evol 13:438-443

Richardson LL (2004) Black band disease. In: Rosenberg E, Loya Y (eds) Coral health and disease. Springer, New York, NY, p 325-336

> Richardson LL, Kuta KG (2003) Ecological physiology of the black band disease cyanobacterium Phormidium corallyticum. FEMS Microbiol Ecol 43:287-298

Rützler K, Santavy DL (1983) The black band disease of Atlantic reef corals I. Description of the cyanophyte pathogen. PSZNI Mar Ecol 4:301-319

Shepard RN (1962) The analysis of proximities: multidimensional scaling with an unknown distance function. Psychometrika 27:125-140

Spalding M, Ravilious C, Green EP 2001. World atlas of coral reefs. University of California Press, Berkeley, CA

Stanley DJ, Swift DJP (1968) Bermuda's reef-front platform: bathymetry and significance. Mar Geol 6:479-500 
Stehli FG, Wells JW (1971) Diversity and age patterns in hermatypic corals. Syst Zool 20:115-126

Sterrer WE (1986) Marine fauna and flora of Bermuda. John Wiley, New York, NY

Stoddart DR (1969) Ecology and morphology of recent coral reefs. Biol Rev Camb Philos Soc 44:433-498

Sutherland KP, Porter JW, Torres C (2004) Disease and immunity in Caribbean and Indo-Pacific zooxanthellate corals. Mar Ecol Prog Ser 266:273-302

Taylor DL (1983) The black band disease of Atlantic reef Corals. II. Isolation, cultivation, and growth of Phormidium corallyticum. PSZNI Mar Ecol 4:321-328

Tchobanoglous G, Kreith F (2002). Handbook of solid waste management. McGraw-Hill, New York, NY

US Environmental Protection Agency (EPA) (2000) Method 1600 Enterococci in water by membrane filtration using membrane-enterococcus indoxyl- $\beta$-D-glucoside agar ( $\mathrm{mEI}$ ). Office of Water, Washington, DC

Editorial responsibility: Peter Edmunds, Northridge, California, USA
Voss JD, Richardson LL (2006) Nutrient enrichment enhances black band disease progression in corals. Coral Reefs 25:569-576

Weil E (2004) Coral reef diseases in the wider Caribbean. In: Rosenberg E, Loya Y (eds) Coral health and disease. Springer, New York, NY, p 35-68

Weil E, Vargas WL (2010) Comparative aspects of sexual reproduction in the Caribbean coral genus Diploria (Scleractinia: Faviidae). Mar Biol 157:413-426

Weil E, Urreiztieta I, Garzon-Ferreira J (2002) Geographic variability in the incidence of coral and octocoral diseases in the wider Caribbean. Proc 9th Int Coral Reef Symp, Bali 2:1231-1238

Wells JW (1973) New and old scleractinian corals from Jamaica. Bull Mar Sci 23:16-58

WHO (2003) Guidelines for safe recreational water environments. Coastal and fresh waters, Vol 1. World Health Organization (WHO), Geneva

Submitted: November 16, 2011; Accepted: May 11, 2012

Proofs received from author(s): 